\title{
GETTING JUSTICE THROUGH LEGAL ASSISTANCE: A COMPARING CASE OF INDONESIA AND MALAYSIA
}

\author{
Riyun Khilmawati Maala* \\ Malaysian Legal Assistance Society, Johar Baru, Malaysia
}

*Email: riyun_maala@gmail.com

\begin{abstract}
Equality before the law should be applied to all citizens impartially. However, there are still discriminatory cases against those who are in lower strata than others. So we need a legal revolution that guarantees the fulfillment of justice which is then used as a source in law enforcement practices, legal protections, and legal services for poor people or groups. In addition to Indonesia, the State of Malaysia is also trying to provide justice for all its citizens by trying to provide legal aid guarantees for its citizens who are experiencing legal problems but are not able to afford it economically. This research is intended to analyze the legal comparison of the implementation of legal aid in the State of Indonesia and the State of Malaysia for the sake of creating justice. The research also aims to find out what obstacles are encountered in the implementation of legal aid in the State of Indonesia and the State of Malaysia for the sake of creating justice.
\end{abstract}

Keywords: Legal Assistance; Justice; Indonesia and Malaysia Policy

The Indonesian Journal of International Clinical Legal Education DOI: https://doi.org/10.15294/ijicle.v3i3.48261

Submitted: Dec 12, 2020 Revised: May 23, 2021 Accepted: July 29, 2021 Available online at https://journal.unnes.ac.id/sju/index.php/iccle (c) 2021 Authors. This work is licensed under a Creative Commons AttributionShareAlike 4.0 International License (CC BY-SA 4.0). All writings published in this journal are personal views of the authors and do not represent the views of this journal and the author's affiliated institutions. 
Riyun Khilmawati Maala

\section{INTRODUCTION}

In the State of Indonesia which is a state of law, the State recognizes and protects the individual rights of every citizen. The recognition of individual rights is guaranteed in the principle of equality before the law (Equality before the law). With equality before the law, it is certain that there is equal treatment for every citizen. It is this equality that guarantees access to justice.

One of the characteristics of the rule of law is that in principle it seeks to provide justice for its citizens through the fulfillment of access to law so that it is not impossible for justice for all Indonesian people to be achieved. Therefore, law enforcement in our beloved country, Indonesia, should run as expected.

However, the law enforcement process in Indonesia still has not produced significant developments in achieving justice and legal certainty for everyone with the lure of equality before the law promised by the State as a legal state in accordance with what is contained in the Constitution of the Republic of Indonesia. Indonesia in 1945 as the state constitution, laws and implementing regulations.

From the first amendment to the last amendment, the state constitution clearly provides guarantees for anyone to get justice regardless of ethnicity, religion, race, inter-group, economic strata, position, and anything that causes discrimination. However, the face of law enforcement in our beloved country, Indonesia, is still very gloomy and concerning. This concern is not only because the legal substance is still limping along with the development of the community's need for the law itself, but also because the entire system that is an effort to enforce the law is still unable to provide the best service for anyone who needs justice.

The high level of public apathy towards the law enforcement process is often the cause of discriminatory practices in law enforcement which should be in line with the guarantees of the State constitution, other laws and regulations, as well as implementing regulations that seek to create justice for the entire community.

Equality before the law should be applied to all citizens impartially. However, there are still discriminatory cases against those who are in a lower strata than others. So we need a legal revolution that guarantees the fulfillment of justice which is then used as a source in law enforcement practices, legal protection, and legal services for poor people or groups. 
In addition to Indonesia, the State of Malaysia is also trying to provide justice for all its citizens by trying to provide legal aid guarantees for its citizens who are experiencing legal problems but they are not able to afford it economically.

Based on the above background, the writer formulates a formulation that will be discussed in this paper, which is as follows:

1. How is the legal comparison of the implementation of legal aid in the State of Indonesia and the State of Malaysia for the sake of creating justice?

2. What are the obstacles encountered in the implementation of legal aid in the State of Indonesia and the State of Malaysia for the sake of creating justice?

\section{COMPARISON OF LEGAL AID IMPLEMENTATION IN INDONESIA AND MALAYSIA FOR THE SAKE OF CREATING JUSTICE}

Comparative law in various foreign terms, including: Comparative Law, Comparative Jurisprudence, Foreigen Law in English, Droit Compare in French, Rechtsvergelijking in Dutch, and Rechtsvergleichung or Vergleichende Rechlehre in German. In Black's Law Dictionary, comparative law or comparative jurisprudence is a study of the principles of law by comparing various legal systems.

Comparative law proposed by G. Guitens-Bourgois is a comparative method applied in legal science. Comparative law is only a method of study that examines something or how it works. Comparison is used as a method that contains an approach to better understand an object or problem under study.

Comparative law as a method according to Sunaryati Hartono, is not seen as a particular area of law, such as land law, law of change or procedural law, comparative law is simply a method of investigating a legal issue, in any field.

Soerjono Soekanto stated that comparative law is useful in terms of providing knowledge about the similarities and differences between various fields of legal order and their basic meanings. Equality in terms of legal uniformity or unification, legal certainty, and legal simplicity. So that they can find out the differences that provide a more solid grip or guideline in terms of legal diversity. 
Riyun Khilmawati Maala

Comparative law will provide materials that can develop or abolish existing laws. ${ }^{1}$

Clarence J. Dias Research on Legal Service and Proverty in the Washington University Law Quarterly defines that legal aid refers to the regulation of legal professional services to ensure that no one can prevent someone from receiving legal advice or being represented before the court due to financial inadequacy.

M. Yahya Harahap means that Legal Aid has different characteristics related to the terms, namely Legal Aid and Legal Assistance. What is meant by Legal aid is to provide free legal aid to someone who is a group of poor people and is blind to the law who is then involved in a legal case or case. In contrast to legal aid, legal assistance has a broader meaning than legal aid, because it is the definition of legal aid that is generally given by the advocate profession to those who cannot afford it, which is given free of charge or by providing honoraria for those who can afford it. ${ }^{2}$

The State of Indonesia is a unitary state with a republican system of government led by a president as head of state. The state power system is divided into legislative, executive and judicial powers. The Indonesian state adheres to a civil law system which therefore makes the law seen by its citizens as everything that becomes a guide in the life of the nation and state.

As an Indonesian citizen, everyone has the right to obtain legal assistance in accordance with the guarantees of Article 27 Paragraph (1) of the 1945 Constitution of the Republic of Indonesia which clearly states that every citizen, together with his position in law and government, is obliged to uphold the law and the government. with no exceptions. In addition to these rights, the Constitution of the Republic of Indonesia in Article 28D Paragraph (1) also states that everyone has the right to recognition, guarantees, protection, and fair legal certainty and equal treatment before the law. ${ }^{3}$

Law No. 18 of 2003 concerning Advocates also provides explicit guarantees and provides no obligation for every advocate except to be able to provide legal assistance free of charge. This is in accordance with what is contained in Article 22 Paragraph (1)

1 Barda Nawawi Arief, Comparative Criminal Law, (Jakarta: Rajawali Pers, 2013), pp. 3-27

2 Yahya Harahap, Discussion and Application of the Criminal Procedure Code: Investigation and Prosecution, (Jakarta: Sinar Graphic, 2009), pp. 344

3 A Patra M. Zen and Daniel Hutagalung, Guide to Legal Aid in Indonesia: Your Guide to Understanding and Resolving Legal Problems, (Jakarta: YLBH, 2006), p. 47 
which states that Advocates are obliged to provide free legal assistance to those seeking justice who cannot afford. ${ }^{4}$

Article 56 of Law Number 48 of 2009 concerning Judicial Power also provides rights for everyone involved in a case to have the right to legal assistance. ${ }^{5}$ In addition, Law no. 8 of 1981 concerning the Criminal Procedure Code or KUHAP states in Article 54 that in terms of the interest of the defense, the suspect or defendant is entitled to obtain legal assistance from legal counsel during the time and at each examination according to the procedure determined by the law. and if the suspect or defendant is an incapacitated group and is suspected or charged with committing a criminal act which is punishable by the death penalty or fifteen years or more then based on the Criminal Procedure Code Article 56 Paragraph (1) and Paragraph (2) can obtain legal assistance from the State through the court. by providing free appointed legal counsel. ${ }^{6}$

The regulation emphasizes that justice has clearly become a human right that must be respected and guaranteed in terms of its fulfillment without distinction of ethnicity, religion, position, economic strata, or other things that cause discrimination. However, these regulations still do not provide satisfaction for justice seekers, both in terms of material and formal rules or practices.

Based on the above situation, the legislators, in this case the government, have enacted Law Number 16 of 2011 concerning Legal Aid, to fulfill and improve the guarantee of the implementation of the right to legal aid which so far is still inadequate.

The existence of Law Number 16 of 2011 concerning Legal Aid provides fresh air for the realization of the fulfillment of the legal rights of citizens in Indonesia, this can be seen in the weighing clause in the Law which states that for the sake of creating justice, the State is responsible for providing legal aid for the poor as a manifestation of access to justice.

In addition to this, referring to the general provisions of the Law which provides a definition of legal aid as legal services provided by Legal Aid Providers which are provided free of charge to Legal Aid Recipients. The legal aid recipients are poor people or citizens who are unable to face the legal process due to financial poverty and legal illiteracy.

In Indonesia itself, there are various types of legal aid, namely as follows: First, Conventional Legal Aid which is legal aid

4 Munir Fuady, Noble Profession, Professional Legal Ethics for Judges, Prosecutors, Advocates, Notaries, Curators, and Management, (Bandung: Ctra Aditya Bakti, 2005), p. 28

5 Article 56 of Law no. 48 of 2009 concerning Judicial Power

6 A Patra M. Zen and Daniel Hutagalung, Op.Cit, p. 48 
Riyun Khilmawati Maala

which is morally and professionally advocates given individually and passively to their clients based on an agreement to provide assistance and defense before the trial in return or honorarium. ; Second, Constitutional Legal Aid in the form of legal aid in an effort to realize a rule of law based on democratic principles and human rights provided by advocates to the poor; Lastly, Structural Legal Aid, namely legal aid that not only provides free legal services to the underprivileged but is also a movement to liberate society from the shackles of political, economic, social,

Article 1 Paragraph (1) of Law Number 16 of 2011 explains that Legal Aid is a legal service provided by Legal Aid Providers free of charge to Legal Aid Recipients. ${ }^{7}$ Before providing legal aid, the legal aid provider must meet requirements such as being a legal entity, being accredited, having a permanent office or secretariat, having an administrator, and having a legal aid program. This is in accordance with what is contained in the Law on Legal Aid Article 8 Paragraph (2). ${ }^{8}$

Legal aid can be given to Legal Aid Recipients in dealing with case processes that include civil law issues, criminal law issues, and state administrative legal issues, both litigation and nonlitigation. ${ }^{9}$ What is meant by litigation settlement above is the process of handling cases that are carried out through court settlements, while non-litigation means that the settlement is carried out outside the court. The provision of non-litigation legal assistance can usually be in the form of legal counseling, legal consultation, electronic and non-electronic case investigations, legal research, mediation, negotiations, community empowerment, out-of-court assistance, and legal drafting. ${ }^{10}$

Litigation grants are provided by advocates who are administrators of legal aid providers or advocates recruited by legal aid providers. Then, if the number of Advocates is insufficient to provide legal assistance to Legal Aid Recipients, then the Legal Aid Provider can recruit Paralegals, lecturers, and law faculty students who in providing legal aid can attach written evidence as a companion Advocate. ${ }^{11}$

Furthermore, Law Number 48 of 2009 concerning Judicial Power in Article 57 states that in every district court a legal aid post is established for those seeking justice who cannot afford. Then the

7 Article 1 Paragraph (1) of Law Number 16 of 2011 concerning Legal Aid Article 8 Paragraph (2) of Law Number 16 of 2011 concerning Legal Aid

9 Article 5 Government Regulation Number 42 of 2013 concerning Terms and Procedures for Providing Legal Aid and Distribution of Legal Aid Funds

10 Article 16 Government Regulation Number 42 of 2013 concerning Terms and Procedures for Providing Legal Aid and Distribution of Legal Aid Funds

11 Article 13 Government Regulation Number 42 of 2013 concerning Terms and Procedures for Providing Legal Aid and Distribution of Legal Aid Funds 
State in relation to legal aid has the duty to bear the costs of providing free legal aid in accordance with Article 68B of Law no. 49 of 2009 concerning General Courts with the provision of attaching a certificate of incapacity from the kelurahan where the relevant domicile is in accordance with what is regulated in $68 \mathrm{~B}$ Paragraph (1) of the Law. ${ }^{12}$

This is different from the advocate's office which is a legal aid provider based on the achievement of the institution's vision and mission. A Legal Aid Institute was formed to provide legal assistance to those who are financially incapable and legally illiterate. So that in the provision of legal aid there are certain criteria to be able to provide legal aid. ${ }^{13}$ The criteria or conditions that usually must be met in order to be granted legal aid by a Legal Aid Institute are as follows: 1) submit a written application containing the identity of the applicant and a brief description of the subject matter for which legal assistance is requested; 2) submit documents relating to the case, such as evidence, etc.; and 3) attach a certificate of poverty from the lurah, village head, or an official at the same level at the place of residence of the legal aid applicant. ${ }^{14}$

In the event that the applicant for legal aid cannot prepare a written application, the application can be submitted verbally directly to the Legal Aid Institute as a Legal Aid Provider, after which the Legal Aid Provider can immediately put it in writing which is then signed or thumbprinted by the applicant. ${ }^{15}$. Then, within a period of no later than 3 (three) working days, an application that is declared complete must obtain an answer regarding the application to then make a special power of attorney. In the event that the application for legal aid is rejected, the legal aid provider must state the reasons for the refusal.

In the event that the legal aid provider accepts the application, ${ }^{16}$ then as a Legal Aid Recipient, he/she has the right to obtain legal assistance until the legal problem is resolved and/or the case has permanent legal force, as long as the Legal Aid Recipient does not revoke his/her power of attorney; then the Legal Aid Recipient is also entitled to get legal assistance in accordance with legal aid standards and/or what is contained in the Advocate's Code of Ethics; and he is also entitled to obtain information and documents

12 Nike Sepvinasari and Zulfikar Judge, Implementation of Providing Free Legal Aid to Poor Defendants at the West Jakarta District Court, Lex Journalica Vol. 12, No. 3, 2015, pp. 238-240.

13 Siti Aminah, Guide to Legal Aid in Indonesia, (Jakarta: Indonesia Obor Foundation, 2009), p. 48

14 Article 14 of Law Number 16 of 2011 concerning Legal Aid

15 Article 10 Government Regulation Number 42 of 2013 concerning Terms and Procedures for Providing Legal Aid and Distribution of Legal Aid Funds

16 Article 15 of Law Number 16 of 2011 concerning Legal Aid 


\section{Riyun Khilmawati Maala}

related to the implementation of the Provision of Legal Aid. ${ }^{17}$ When there are rights that are obtained there are also obligations that must be given by the Legal Aid Recipient in terms of providing legal aid. Recipients of Legal Aid are required to submit evidence, information, and/or information on the case to be faced to the Legal Aid Provider. ${ }^{18}$

Malaysia is a federation consisting of 13 (thirteen) states and 3 (three) federated territories with Kuala Lumpur as the capital city and Putrajaya as the center of government. The state of Malaysia adheres to a common law system and the Malaysian Constitution of 31 August 1957 is considered the highest law in Malaysia. The constitution stipulates the structure of government by guaranteeing basic rights for every citizen as regulated by the Constitution of the State of Indonesia, namely the 1945 Constitution of the Republic of Indonesia.

Article 5 Paragraph (3) of the Malaysian Constitution states that the State guarantees the right of everyone to be legally represented in the court system. In addition, it is also stated in Article 8 Paragraph (1) of the Malaysian Constitution that the constitution guarantees that everyone is equal before the law.

In relation to the practice of Legal Aid, Legal Aid in Malaysia is regulated in Act 26 the Legal Aid act 1971 Concerning Legal Aid. The law provides guarantees for citizens who are in conflict with the law, that they can still obtain legal assistance such as obtaining free legal consultation and legal assistance provided that they are underprivileged communities as evidenced by proof of income and must meet further tests .

The Legal Aid is given to the Legal Aid Recipient who is a person who has been given a certificate stating that he or she is entitled to legal assistance. ${ }^{19} \mathrm{~A}$ legal aid certificate as a condition for providing legal aid is submitted to the court or the Director General of Legal Aid which will be forwarded to the Director of Social Welfare to state that the applicant is a poor citizen. In the process of making the certificate, the applicant is charged a registration fee of RM 2 which can be paid in a lump sum or in installments. The granting of the certificate is based on reasonable reasons and really the applicant is a poor community as evidenced by his income of not more than RM 30000 per year. Legal Aid Providers are a panel of lawyers appointed by the Director General of Legal Aid to be willing to investigate and provide their opinion in providing legal aid. ${ }^{20}$

\footnotetext{
Article 12 of Law Number 16 of 2011 concerning Legal Aid

Article 13 of Law Number 16 of 2011 concerning Legal Aid

Article 2, Act 26 the Legal Aid act 1971

Article 5 (1), Act 26 the Legal Aid act 1971
} 
In Malaysia, there are also legal aid organizations that can provide legal assistance in both civil cases, criminal cases, and sharia cases. These organizations consisted of lawyers who later established a legal aid center clinic and also a sharia clinic. In Malaysia, lawyers who have just graduated must serve voluntarily for a period of 9 (nine) months. ${ }^{21}$

\section{OBSTACLES ENCOUNTERED IN THE IMPLEMENTATION OF LEGAL AID IN INDONESIA AND MALAYSIA FOR THE SAKE OF CREATING JUSTICE}

Satjipto Rahardjo stated that as a law enforcement system, law enforcement is essentially a variable that has correlation and interdependence with other factors outside the system. ${ }^{22}$ According to Lawrence M. Friedman, several factors determine the occurrence of the law enforcement process, namely due to the components of legal substance, legal structure, and legal culture. These components then become components or factors that determine the success or failure of the law enforcement process which is also a factor that will determine how the process of implementing legal aid in the State of Indonesia and the State of Malaysia in achieving justice for its citizens.

The creation of justice is one of the goals of a state of law which then through the government seeks to provide access to justice which basically focuses on the existing legal system. Justice should be accessible to every citizen without discrimination and the existing legal system should be able to produce provisions in legal products that are fair to all groups, both individuals and groups.

Access to justice in question has the meaning of equality with the right to obtain, use, and benefit from the justice process obtained through litigation and non-litigation that allows underprivileged and legally blind people to get the same guarantees and recognition as those who are able to use the facilities and services. legal facilities to obtain material justice and truth. This is a priority in the concept of accessing justice so as to create social justice for all citizens.

In Indonesia, until now, the initiative to reform law enforcement institutions in Indonesia still focuses on formal state institutions, even though in reality justice is not only in the realm of

21 Zaid Ibrahim \& Co, Pro Bono Practices and Opportunities in Malaysia, Latham \& Watkins LLP, pp. 402-408

22 Satjipto Rahardjo, Law Enforcement: A Sociological Review, (Jakarta: Genta Publishing, 2009), p. viii 
Riyun Khilmawati Maala

the state. To cause support and attention in the need to obtain justice for marginalized groups, minorities, is still very clearly discriminatory.

There are still many behaviors of actors in the judiciary who still do not uphold the value of justice, even less authoritativeness when faced with parties who have relations and are more powerful, on the other hand the actors are even more authoritative when faced with people who incidentally have no power and are considered little people. These things have resulted in the marginalization of the people who do not have any power and eventually resulted in structural violence. The reality of the rule of law and equality before the law (equality before the law) as well as an independent and impartial judiciary as one of the requirements for a state of law is still just wishful thinking. ${ }^{23}$

This shows the dilapidated face of law enforcement in our beloved country, Indonesia. In addition, the understanding of our law enforcement officers is still conservative who thinks that all forms of violations and crimes must be processed through existing legal procedures. Whereas in the concept of the Criminal Justice System, it has long been trying to change the enforcement system which only focuses on retaliation in sentencing or retributive justice to restorative justice, so that in law enforcement it should be able to turn into restorative justice which emphasizes on restoring the condition of criminals, victims of crime, and communities affected by crime.

In addition to the above law enforcement factors, factors outside of law enforcement are also a determinant of the implementation of law enforcement by providing legal assistance for citizens, namely covering the existing facilities and facilities. As stated by Soerjono Soekanto, without the means and facilities, it is impossible for law enforcement to take place in accordance with the wishes of the State and citizens. Facilities or facilities such as educated and skilled human resources, the existence of a good organization, the existence of adequate supporting equipment, funding, and so on which should then be fulfilled by the State. ${ }^{24}$

Indonesian people still have a low level of awareness and understanding of the law so they do not know what their rights are and what their obligations are. This ignorance makes underprivileged citizens not know that they can get legal aid without

23 M. Irsyad Thamrin, etc., Yogyakarta Legal Aid Institute, (Yogyakarta: LBH Yogyakarta, 2010), pp. 1-2

24 Soerjono Sokanto, Factors Affecting Law Enforcement, (Jakarta: PT Raja Grafndo Persada, 2011), p. 37 
paying (pro bono public) when those who can afford it can hire the services of a lawyer. ${ }^{25}$

But there are times when there are community groups who know what their rights and obligations are and know that there is legal assistance that the State can provide as a guarantee of obtaining justice, but they do not have the courage to use these facilities because everything is of course returned to individual citizens as the determinant.

Legal culture in Indonesia is basically in the form of values that underlie applicable law. Values are abstract conceptions about what is seen as something good which is then followed or adopted and about what is considered bad so that it is avoided. The values that already exist above should be harmonized or even separated so that the ideals of law enforcement in our country can be realized.

Malaysia as a country that also strives to provide justice for every citizen in terms of providing legal assistance also still has gaps in its implementation. The existing law on legal aid still does not eliminate discrimination in obtaining justice, because citizens who wish to obtain legal aid are required to have a certificate in advance and their application is also subject to fees.

In addition, financial constraints are also an obstacle faced by the State of Malaysia in its efforts to provide legal assistance for every citizen. Because basically the implementation of assistance in a country in order to realize justice comes from funding.

Then the lack of awareness and negative perception that citizens have of the judicial system is also the reason for the difficulty of providing legal assistance which in the end also hinders the State's efforts to provide justice for its citizens. ${ }^{26}$

\section{CONCLUSION}

As a state of law, the State of Indonesia and the State of Malaysia through the government make policies and in implementing these policies based on the laws that have been regulated. The law is a representation of the people, so with the existence of the State Constitution and legislation and their implementation should be in accordance with the wishes of the people. A strong desire that the State will guarantee the achievement of justice for the people by getting equal treatment before the law, as well as guarantees for the people to get justice (justice for all and access to justice). The implementation of providing legal assistance to citizens as an effort

25 Ishaq, Fundamentals of Legal Studies, (Jakarta: Snar Graphics, 2008), p. 71

26 Andika Wahab and Aizat Khairi, Right to Justice and Legal Aid Barriers to the Vulnerable Non-Citizens in Malaysia, Geografia Malaysia Journal of Society and Space No. 6 Vol. 1, pp. 18-20 
Riyun Khilmawati Maala

to realize justice and legal certainty that is not discriminatory is a very difficult effort for a country. The conception and role of a legal aid institution in a country must be different from one another, both the Indonesian state and the Malaysian state where the legal aid institution was born and raised. The difference can be seen how much intervention from the government on the existence of the legal aid institution which is usually closely related to the level of economic growth and the level of education of the citizens. In this case not only aspects of the judicial process. The legal products contained in the State of Indonesia and the State of Malaysia emphasize that justice has clearly become a human right that must be respected and guaranteed in terms of its fulfillment without distinction of ethnicity, religion, position, economic strata, or other things that cause discrimination. However, these regulations still do not provide satisfaction for justice seekers, both in terms of material and formal rules or practices.

\section{V.SUGGESTIONS}

Factors of legal substance, legal structure, and cultural or legal culture are components that determine the success or failure of the law enforcement process which is also a factor that will determine how the process of implementing legal aid in the State of Indonesia and the State of Malaysia in achieving justice for citizens. his country. With various existing legal products, all of which regulate legal aid, it should have become one of the guarantees from the State for its citizens to get justice. But with the existence of these legal products, there are still those who do not get the justice they deserve due to the obstacles mentioned above. So there should be a synchronization of all the factors that determine the success of the implementation of legal aid, such as laws and regulations governing legal aid which then synergize with institutions that provide legal aid by creating cadres who understand and understand how to create justice for the people. all seekers of justice. In addition to this, the community as citizens should strive to support all things that have been pursued by the State through the government which has played an active role in enforcing the law to create justice by knowing their roles, rights and obligations as citizens. 


\section{REFERENCES}

Amen, S. (2009). Guide to Legal Aid in Indonesia. Jakarta: Yayasan Obor Indonesia

Arief, B. N. (2013). Perbandingan Hukum Pidana. Jakarta: Rajawali Press

Fuady, M. (2005). Noble Profession, Legal Professional Ethics for Judges, Prosecutors, Advocates, Notaries, Curators, and Management. Bandung: Ctra Aditya Bakti

Ibrahim, Z., \& Co. (2015). Pro Bono Practices and Opportunities in Malaysia. Latham \& Watkins LLP

Indonesia. (1981). Law Number 8 of 1981 concerning the Criminal Procedure Code

Indonesia. (2003). Law Number 18 of 2003 concerning Advocates

Indonesia. (2009). Law No. 48 of 2009 concerning Judicial Power

Indonesia. (2009). Law No. 49 of 2009 concerning General Courts

Indonesia. (2011). Law Number 16 of 2011 concerning Legal Aid

Indonesia. (2013). Government Regulation Number 42 of 2013 concerning Terms and Procedures for Providing Legal Aid and Distribution of Legal Aid Funds

Isaac, I. (2008). Fundamentals of Legal Studies. Jakarta: Sinar Graphic

Malaysia. (1971). Laws of Malaysia, Act 26 Legal Aid Act 1971

Please, Y. (2009). Discussion and Implementation of the Criminal Procedure Code: Investigation and Prosecution. Jakarta: Sinar Graphic

Rahardjo, S. (2009). Law Enforcement: A Sociological Review. Jakarta: Genta Publishing

Sepvinasari, N., \& Hakim, Z. (2015). Implementation of Providing Free Legal Aid to Poor Defendants at the West Jakarta District Court. Lex Journalica, 12(3).

Sokanto, S. (2011). Factors Affecting Law Enforcement. Jakarta: PT Raja Grafndo Persada

Thamrin, M. I., et.al. (2010). Yogyakarta Legal Aid Institute. Yogyakarta: LBH Yogyakarta

Wahab, A., Khairi, A. (2019). Right to Justice and Legal Aid Barriers to the Vulnerable Non-Citizens in Malaysia, Geografia Malaysia Journal of Society and Space, 6(1).

Zen, A. P. M., Hutagalung, D. (2006). A Guide to Legal Aid in Indonesia: Your Guide to Understanding and Resolving Legal Issues. Jakarta: YLBHI. 
Riyun Khilmawati Maala

\section{Conflicting Interest Statement}

All authors declared that there is no potential conflict of interest on publishing this article.

\section{Funding}

None

\section{Publishing Ethical and Originality Statement}

All authors declared that this work is original and has never been published in any form and in any media, nor is it under consideration for publication in any journal, and all sources cited in this work refer to the basic standards of scientific citation.

Cite this article as:

Maala, R. K. (2021). Getting Justice through Legal Assistance: A Comparing Case of Indonesia and Malaysia. The Indonesian Journal of International Clinical Legal Education, 3(3), 353-366. https://doi.org/10.15294/ijicle.v3i3.48261 